\title{
Vasopressin-stimulated $\mathrm{Ca}^{2+}$ influx in rat hepatocytes is inhibited in high-K ${ }^{+}$medium
}

\author{
Anne L. SAVAGE, Mark BIFFEN* and B. Richard MARTIN $\dagger$ \\ Department of Biochemistry, University of Cambridge, Tennis Court Road, Cambridge CB2 1QW, U.K.
}

\begin{abstract}
We examined the effects of $\mathrm{K}^{+}$substitution for $\mathrm{Na}^{+}$on the response of hepatocytes to vasopressin, and on the hepatocyte plasma-membrane potential. (1) High $\mathrm{K}^{+}(114 \mathrm{~mm})$ had no effect on the initial increase in phosphorylase $a$ activity in response to vasopressin, but abolished the ability of the hormone to maintain increased activity beyond $10 \mathrm{~min}$. With increasing concentrations a decrease in the vasopressin response was first observed at $30-50 \mathrm{mM}-\mathrm{K}^{+}$. (2) High $\mathrm{K}^{+}(114 \mathrm{~mm})$ had no effect on basal ${ }^{45} \mathrm{Ca}^{2+}$ influx, but abolished the ability of vasopressin to stimulate influx. This effect was also first observed at a concentration of 30-50 mM$\mathrm{K}^{+}$. (3) Increasing $\mathrm{K}^{+}$had little effect on the plasma-membrane potential until a concentration of $40 \mathrm{~mm}$ was reached. With further increases in concentration the plasma membrane was progressively depolarized. (4) Replacement of $\mathrm{Na}^{+}$with $N$-methyl-D-glucamine ${ }^{+}$depolarized the plasma membrane to a much smaller extent than did replacement with $\mathrm{K}^{+}$, and was also much less effective in inhibiting the vasopressin response. (5) The plasma-membrane potential was restored to near the control value by resuspending cells in normal$\mathrm{K}^{+}$medium after exposure to high- $\mathrm{K}^{+}$medium. The effects of vasopressin on phosphorylase activity were also restored. (6) We conclude that the $\mathrm{Ca}^{2+}$ channels responsible for vasopressin-stimulated $\mathrm{Ca}^{2+}$ influx are closed by depolarization of the plasma membrane.
\end{abstract}

\section{INTRODUCTION}

It is well established that $\mathrm{Ca}^{2+}$-mobilizing hormones act through stimulation of polyphosphoinositide breakdown to release inositol 1,4,5-trisphosphate and diacylglycerol. Diacylglycerol activates protein kinase $C$, and inositol 1,4,5-trisphosphate mediates the release of $\mathrm{Ca}^{2+}$ from the endoplasmic reticulum. This is responsible for the early phase of the increase in cytoplasmic $\mathrm{Ca}^{2+}$ (reviewed by Berridge, 1987). The continuation of the hormone response requires influx of $\mathrm{Ca}^{2+}$ across the plasma membrane to maintain increased cytoplasmic $\mathrm{Ca}^{2+}$ (Reinhart et al., 1984a,b; Mauger et al., 1984; Joseph et al., 1985). The control of this part of the signal mechanism is less well characterized. It has been suggested that inositol 1,3,4,5-tetrakisphosphate, which is produced by phosphorylation of inositol 1,4,5-trisphosphate, may control the $\mathrm{Ca}^{2+}$ channels which are responsible for the $\mathrm{Ca}^{2+}$ influx (Hansen et al., 1986; Irvine \& Moor, 1986).

The $\mathrm{Ca}^{2+}$ channels involved in the hormonal stimulation of $\mathrm{Ca}^{2+}$ uptake are not well characterized, but it has been shown that they are distinct from the voltagedependent channels responsible for $\mathrm{Ca}^{2+}$ influx in excitable cells. Agents such as verapamil, which are specific inhibitors of $\mathrm{Ca}^{2+}$ flux through voltage-dependent channels, are ineffective in liver and other non-excitable cells unless they are employed at concentrations several orders of magnitude higher than those required to inhibit $\mathrm{Ca}^{2+}$ influx in excitable cells (Blackmore et al., 1984; Hughes et al., 1986). At these concentrations it is likely that the effect of the $\mathrm{Ca}^{2+}$-channel blockers is the result of nonspecific effects on the plasma membrane.

Hormones which increase cytoplasmic $\mathrm{Ca}^{2+}$ also alter $\mathrm{K}^{+}$fluxes across the plasma membrane, and this is probably associated with an increase in the plasmamembrane potential. In guinea-pig liver increased cytoplasmic $\mathrm{Ca}^{2+}$ mediates an increase in the $\mathrm{K}^{+}$permeability of the plasma membrane by activating a $\mathrm{Ca}^{2+}$-dependent $\mathrm{K}^{+}$channel (Burgess et al., 1979). This results in an efflux of $\mathrm{K}^{+}$and hyperpolarization as the plasma-membrane potential moves towards the $\mathrm{K}^{+}$-diffusion potential (Jenkinson \& Koller, 1977; Cocks et al., 1984). In rat liver, $\mathrm{Ca}^{2+}$-mobilizing hormones also stimulate $\mathrm{a} \mathrm{K}^{+}$efflux which is preceded by a transient $\mathrm{K}^{+}$influx (Friedmann \& Park, 1968; Capiod et al., 1982; Reinhart et al., 1984a). However, the rat liver plasma membrane does not contain a $\mathrm{Ca}^{2+}$-dependent $\mathrm{K}^{+}$channel (Burgess et al., 1979), but the initial $\mathrm{K}^{+}$influx is thought to result from activation of the $\mathrm{Na}^{+} / \mathrm{K}^{+}$-ATPase (Capiod et al., 1982; Lynch et al., 1986). Activation of the $\mathrm{Na}^{+} / \mathrm{K}^{+}$-ATPase might also be expected to lead to hyperpolarization of the plasma membrane.

There is some evidence that changes in membrane potential may modulate the $\mathrm{Ca}^{2+}$ signal. In human neutrophils, depolarization of the plasma membrane inhibited stimulation of $\mathrm{Ca}^{2+}$ influx by $\mathrm{fMet}-\mathrm{Leu}-\mathrm{Phe}$ and also release of $\mathrm{Ca}^{2+}$ from intracellular pools. Hyperpolarization increased the duration of the rise in cytoplasmic $\mathrm{Ca}^{2+}$ (Di Virgilio et al., 1987). Depolarization decreased the rise in cytoplasmic $\mathrm{Ca}^{2+}$ in response to lectins in T-lymphocytes, and lectins hyperpolarized the

Abbreviation used: $\mathrm{NMDG}^{+}, N$-methyl-D-glucamine ${ }^{+}$.

* Present address: Department of Botany, University of Cambridge, Downing Street, Cambridge CB2 3EA, U.K.

$\dagger$ To whom correspondence should be addressed. 
plasma membrane (Tsien et al., 1982; Gelfand et al., 1984). In rat hepatocytes high external $\mathrm{K}^{+}$, a condition which will depolarize the plasma membrane, abolished the activation of phosphorylase by phenylephrine (van de Werve et al., 1977).

In this paper, we set out to examine the effects of plasma-membrane depolarization on hormone-stimulated $\mathrm{Ca}^{2+}$ influx and phosphorylase activation in rat hepatocytes. The $\mathrm{Ca}^{2+}$ influx response is abolished and the duration of phosphorylase activation is markedly decreased as a result of membrane depolarization.

\section{EXPERIMENTAL}

\section{Materials}

${ }^{45} \mathrm{CaCl}_{2},\left[{ }^{3} \mathrm{H}\right]$ inulin and ${ }^{3} \mathrm{H}_{2} \mathrm{O}$ were obtained from Amersham Corp. [Arginine]vasopressin and bovine serum albumin (fraction V) were from Sigma. Di-n-butyl phthalate and dinonyl phthalate were obtained from BDH Chemicals. Collagenase was from Boehringer Corp. All other reagents were of analytical grade.

\section{Hepatocyte isolation and incubation}

Hepatocyte isolation was based on the method of Berry \& Friend (1969) with several modifications. Female Wistar rats $(160-180 \mathrm{~g})$ were anaesthetized and the livers were perfused with $\mathrm{Ca}^{2+}$-free Krebs bicarbonate buffer (Krebs \& Henseleit, 1932), pH 7.4, containing 5 mMglucose, gassed continuously with $\mathrm{O}_{2} / \mathrm{CO}_{2}(19: 1)$. The buffer entered the liver at $37^{\circ} \mathrm{C}$ through the hepatic portal vein and flowed to waste via the inferior vena cava. After $250 \mathrm{ml}$ of this buffer had been run through the liver, the buffer was changed to normal- $\mathrm{Ca}^{2+}$ (1.3 mM) Krebs buffer containing $0.2 \mathrm{~g}$ of dialysed bovine serum albumin $/ 100 \mathrm{ml}, 5 \mathrm{~mm}$-glucose and $60 \mathrm{mg}$ of collagenase $/ 100 \mathrm{ml}$. This was recirculated through the liver for $15-20 \mathrm{~min}$, by which time a suitable degree of digestion, as judged by increasing leakiness, had been achieved. The liver was removed and placed in normal$\mathrm{Ca}^{2+}$ Krebs buffer containing $5 \mathrm{~mm}$-glucose. The cells were dispersed, filtered through nylon mesh (aperture $0.125 \mathrm{~mm}$ ), centrifuged at $64 \mathrm{~g}$ for $2 \mathrm{~min}$ and then resuspended in the same buffer. This washing procedure was repeated twice and the cells were finally resuspended in Krebs bicarbonate buffer containing $2 \mathrm{~g}$ of dialysed albumin/100 ml, $5 \mathrm{~mm}$-glucose, $10 \mathrm{~mm}$-lactate, $1 \mathrm{~mm}$ pyruvate, $2 \mathrm{~mm}$-glutamine and $1 \mathrm{mg}$ of inositol $/ 100 \mathrm{ml}$.

At this stage more than $90 \%$ of the cells were viable, as determined by Trypan Blue exclusion. After a $30 \mathrm{~min}$ preincubation the cells were filtered, washed and resuspended in 5-8 $\mathrm{ml}$ of the same buffer to give a density of approx. $40 \mathrm{mg}$ dry cell wt. $/ \mathrm{ml}$, and incubated for a further $5 \mathrm{~min}$. Experimental incubations were initiated by diluting the isolated hepatocytes 10 -fold into the experimental buffer. For the control this was the same buffer. For high- $\mathrm{K}^{+}$buffer the cells were diluted into Krebs bicarbonate in which the $\mathrm{NaCl}(120 \mathrm{~mm})$ was replaced by $\mathrm{KCl}$. This gave final concentrations of $37 \mathrm{mM}$ for $\mathrm{Na}^{+}$and $114 \mathrm{~mm}$ for $\mathrm{K}^{+}$. All incubations were at $37^{\circ} \mathrm{C}$ in a shaking water bath under an atmosphere of $\mathrm{O}_{2} / \mathrm{CO}_{2}(19: 1)$.

\section{Phosphorylase $a$ assay}

Samples were removed from hepatocyte incubations and stopped and stored as described by Joseph \& Williamson (1983). The cell samples $(0.2 \mathrm{ml})$ were added to $0.2 \mathrm{ml}$ of phosphorylase extraction medium containing 100 mM-Mops (pH 7.0), $150 \mathrm{~mm}-\mathrm{NaF}, 20 \mathrm{~mm}$-EDTA, $400 \mathrm{~mm}$-sucrose, $5 \mathrm{~mm}$-dithiothreitol and $30 \mathrm{mg}$ of Triton $\mathrm{X}-100 / 100 \mathrm{ml}$. Phosphorylase $a$ activity was determined by the method of Stalmans \& Hers (1975). Stopped samples were thawed, and a $0.1 \mathrm{ml}$ portion was added to $0.1 \mathrm{ml}$ of phosphorylase $a$ activity medium, containing $2 \mathrm{~g}$ of glycogen $/ 100 \mathrm{ml}, 100 \mathrm{~mm}$-glucose 1-phosphate, $225 \mathrm{~mm}-\mathrm{NaF}, 1 \mathrm{~mm}$-caffeine (pH 6.1), and incubated at $30{ }^{\circ} \mathrm{C}$ for $30 \mathrm{~min}$. The reaction was stopped by addition of $0.5 \mathrm{ml}$ of $10 \%$ (w/v) trichloroacetic acid, followed by centrifugation $(13000 \mathrm{~g}, 1 \mathrm{~min})$ to remove precipitated protein. The supernatant was sampled $(0.35 \mathrm{ml})$ and assayed for released $P_{i}$ as described by van de Werve et al. (1974).

\section{Cell separation}

Cells were separated from medium by centrifuging through a mixture of dinonyl phthalate and dibutyl phthalate $(1: 4, v / v)$ in a Beckman microfuge. For determination of ${ }^{45} \mathrm{Ca}^{2+}$ efflux, ${ }^{3} \mathrm{H}_{2} \mathrm{O}$ and $\left[{ }^{3} \mathrm{H}\right]$ inulin spaces, $0.2 \mathrm{ml}$ samples of cells were centrifuged through $0.2 \mathrm{ml}$ of separation oil. Sample $(0.15 \mathrm{ml})$ of supernatant was taken for scintillation counting, remaining supernatant and oil were aspirated away, and final traces of liquid were removed with a tissue, with care not to disturb the pellet. Triton X-100 was added to dissolve the pellet, followed by scintillation fluid.

Initial rates of ${ }^{45} \mathrm{Ca}^{2+}$ uptake were determined over $3 \mathrm{~min}$. Hepatocytes were incubated in the presence of $1 \mu \mathrm{Ci}$ of ${ }^{45} \mathrm{Ca}^{2+} / \mathrm{ml}$ and $4 \mu \mathrm{Ci}$ of $\left[{ }^{3} \mathrm{H}\right]$ inulin $/ \mathrm{ml}$. Samples $(0.2 \mathrm{ml})$ were pipetted into $0.8 \mathrm{ml}$ of ice-cold $0.9 \% \mathrm{NaCl}$ containing $15 \mathrm{~mm}-\mathrm{CaCl}_{2}$ above $0.2 \mathrm{ml}$ of separation oil. The purpose of the $\mathrm{CaCl}_{2}$ was to decrease the contribution of ${ }^{45} \mathrm{Ca}$ binding to the outer surface of the plasma membrane. After centrifugation the samples were treated as above, except that $0.5 \mathrm{ml}$ of supernatant was taken.

\section{ATP determination}

Cell samples $(0.2 \mathrm{ml})$ were added to $0.04 \mathrm{ml}$ of ice-cold $0.7 \mathrm{M}-\mathrm{HClO}_{4}$. The precipitated protein was spun down and the supernatant neutralized with $2 \mathrm{M}$-triethanolamine/KOH, $\mathrm{pH} 14$. The precipitated $\mathrm{KClO}_{4}$ was spun down and the supernatant assayed for ATP by the luminometric method described by Bergmeyer (1985).

\section{Determination of plasma-membrane potential}

Plasma-membrane potentials were determined essentially as described by Bradford et al. (1985). It was assumed that the plasma-membrane potential is equal to the equilibrium potential for $\mathrm{Cl}^{-}$. The cells $(14 \mathrm{mg}$ dry wt./ml) were incubated in the presence of $0.7 \mu \mathrm{Ci}$ of ${ }^{36} \mathrm{Cl}^{-} / \mathrm{ml}$. Uptake of label reached a steady state after $15 \mathrm{~min}$. Samples $(0.5 \mathrm{ml})$ were taken and the cells centrifuged through $0.2 \mathrm{ml}$ of separation oil as before. Uptake of ${ }^{36} \mathrm{Cl}^{-}$was determined, taking account of the $\mathrm{H}_{2} \mathrm{O}$ and inulin spaces. The $\mathrm{Cl}^{-}$equilibrium potential was determined from the Nernst equation.

\section{RESULTS AND DISCUSSION}

Fig. 1 shows the effects of vasopressin on phosphorylase $a$ activity in hepatocytes. In normal Krebs buffer the increase in phosphorylase activity persisted for $15 \mathrm{~min}$, the duration of the experiment. In high- $\mathrm{K}^{+}(114 \mathrm{~mm})$ buffer the initial activation was the same as in normal 


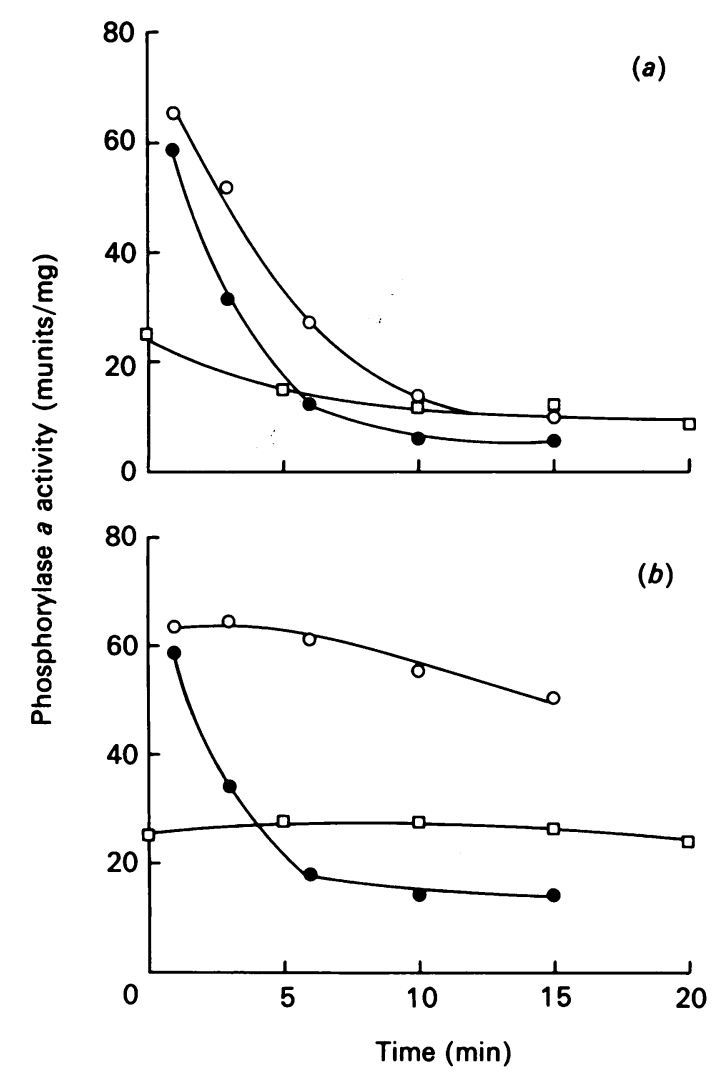

Fig. 1. Vasopressin-stimulated phosphorylase $a$ activity in control or $\mathbf{K}^{+}$buffer

Hepatocytes were incubated in $(a) \mathrm{K}^{+}$or $(b)$ normal buffer in the absence $(\square)$ or presence $(O, O)$ of vasopressin $(10 \mathrm{nM})$ without $(\mathrm{O}, \square)$ or with $(\bigcirc) 2.5$ mm-EGTA. Samples were taken at the indicated times and assayed for phosphorylase $a$ activity in duplicate (see the Experimental section). The result is representative of three such experiments performed on different cell preparations: S.E.M. was within $5 \%$ of values indicated.

buffer, but the activity declined to the non-stimulated value by $10 \mathrm{~min}$. If EGTA $(2.5 \mathrm{~mm})$ was added at the same time as vasopressin, to chelate the extracellular $\mathrm{Ca}^{2+}$, phosphorylase activity declined rapidly to basal values in both normal and high- $\mathrm{K}^{+}$buffer. This implies that stimulated influx of $\mathrm{Ca}^{2+}$ is required to maintain the increase in phosphorylase activity, as reported previously (Joseph et al., 1985). It appears that in high- $\mathrm{K}^{+}$medium vasopressin was able to bind to its receptor and mediate the mobilization of $\mathrm{Ca}^{2+}$ from intracellular stores, since the initial increase in phosphorylase $a$ activity was unchanged. However, the hormone's ability to activate $\mathrm{Ca}^{2+}$ influx appears to have been blocked by exposure of the cells to high- $\mathrm{K}^{+}$medium.

Fig. 2 shows the effects of vasopressin on ${ }^{45} \mathrm{Ca}^{2+}$ influx into hepatocytes. In normal buffer vasopressin stimulated influx over a $3 \mathrm{~min}$ period by about $70 \%$. Increasing the concentration of $\mathrm{K}^{+}$in the buffer at the expense of $\mathrm{Na}^{+}$ had no effect on ${ }^{45} \mathrm{Ca}^{2+}$ influx in the absence of hormone, but progressively decreased the stimulation of influx until at $114 \mathrm{~mm}-\mathrm{K}^{+}$the stimulation by vasopressin was abolished. Efflux of ${ }^{45} \mathrm{Ca}^{2+}$ from preloaded hepatocytes was also stimulated by vasopressin (Fig. 3). High-K ${ }^{+}$ medium had no effect on either the stimulated or the unstimulated rate. These results give further support to

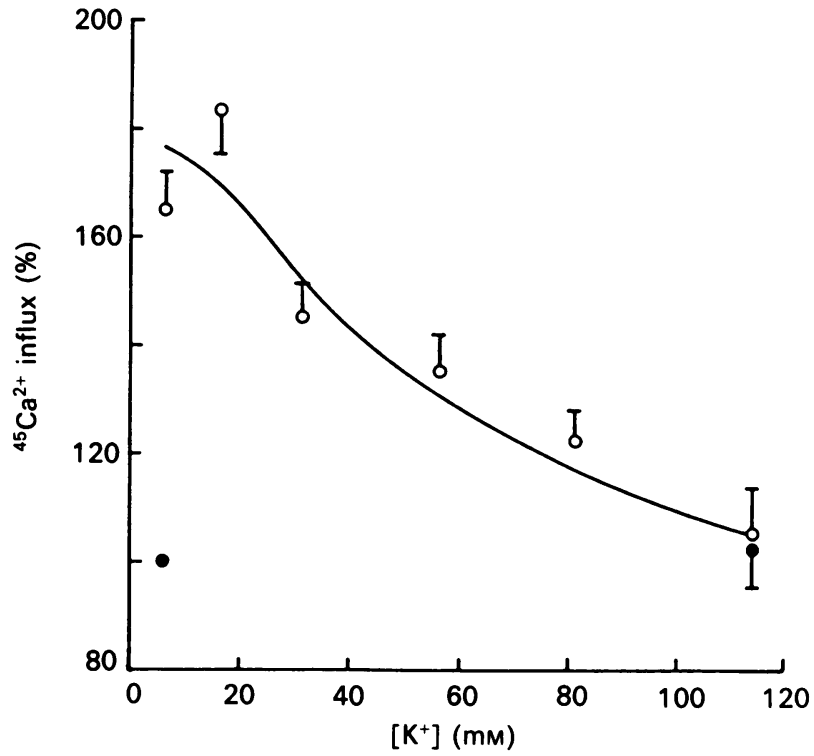

Fig. 2. Vasopressin-stimulated ${ }^{45} \mathrm{Ca}^{2+}$ influx at different $\mathrm{K}^{+}$concentrations

Cells were diluted into incubation buffer containing various $\left[\mathrm{K}^{+}\right]$. Incubation conditions and sampling were the same as described in Table 2. Incubations contained $10 \mathrm{~nm}$-vasopressin (O) or no additions (O). The result is the combination of two such experiments performed on different cell preparations.

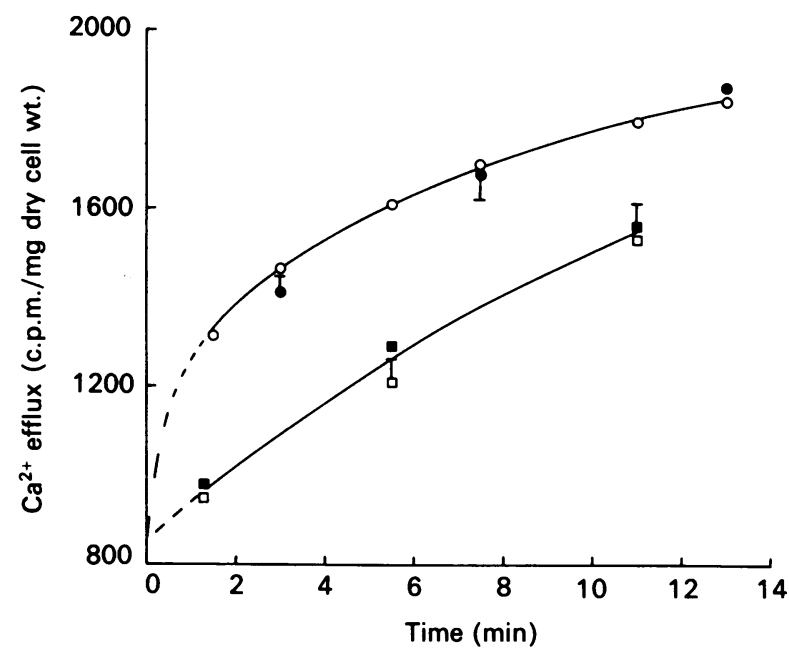

Fig. 3. Basal and vasopressin-stimulated ${ }^{45} \mathrm{Ca}^{2+}$ efflux in normal or $\mathbf{K}^{+}$buffer

Hepatocytes were incubated with $1 \mu \mathrm{Ci}$ of ${ }^{45} \mathrm{Ca}^{2+} / \mathrm{ml}$ for $1 \mathrm{~h}$, washed twice in $\mathrm{Ca}^{2+}$-containing Krebs bicarbonate buffer and resuspended in incubation buffer. Immediately samples were diluted 10 -fold into control $(\square, \bigcirc)$ or $\mathrm{K}^{+}$ buffer $(\square, \bigcirc)$, with $(\bigcirc, \bigcirc)$ or without $(\square, \square)$ vasopressin (10 nM). Triplicate samples were taken from single incubations and spun through separation oil for basal efflux. Incubations with vasopressin were performed in duplicate, and the sampling regime resulted in cells in normal buffer being sampled at staggered intervals, whereas the points in $\mathrm{K}^{+}$buffer are the mean of duplicate incubations. S.E.M., unless shown, was less than $3 \%$ of the mean value plotted. 


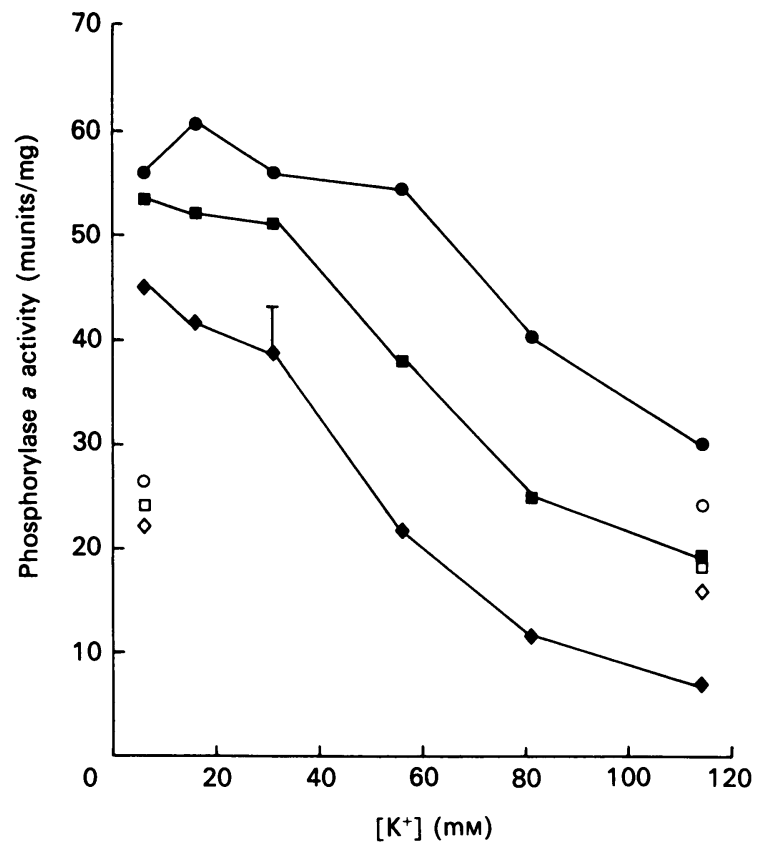

Fig. 4. Effect of varying $\left[\mathrm{K}^{+}\right]$on vasopressin-stimulated phosphorylase $a$ activity

Hepatocytes were diluted 10 -fold into buffers made up with various concentrations of $\mathrm{NaCl}$ and $\mathrm{KCl}$ to give the indicated $\left[\mathrm{K}^{+}\right]$. Samples were taken at $3 \mathrm{~min}(\mathrm{O}, \mathrm{O}), 5 \mathrm{~min}$ $(\square, \square)$ or $10 \mathrm{~min}(\diamond, \diamond)$ with $(\bigcirc, \square, \diamond)$ or without $(\bigcirc$, $\square, \diamond)$ vasopressin $(10 \mathrm{~nm})$, which was present at zero time. Points were determined in duplicate and are representative of three such experiments performed on different cell preparations. Unless indicated otherwise, S.E.M. was less than $4 \%$ of the mean value.

the conclusion that high- $\mathrm{K}^{+}$medium blocks vasopressinstimulated $\mathrm{Ca}^{2+}$ influx, but has no effect on the ability of vasopressin to initiate a response by promoting release of $\mathrm{Ca}^{2+}$ from intracellular stores. The interpretation of the results shown in Fig. 3 could be complicated by the effect of high- $\mathrm{K}^{+}$medium on $\mathrm{Ca}^{2+}$ influx, altering the specific radioactivity of the intracellular $\mathrm{Ca}^{2+}$ pools. However, this is unlikely to be significant at the short time periơds. employed.

The effect of varying the extent of replacement of $\mathrm{Na}^{+}$ with $\mathrm{K}^{+}$on phosphorylase $a$ activity is shown in Fig. 4 . If phosphorylase $a$ activity was determined after 3 min exposure to vasopressin, over $50 \mathrm{~mm}-\mathrm{K}^{+}$was required to decrease the response. If phosphorylase $a$ activity was measured after a longer exposure to hormone $(10 \mathrm{~min})$, over $30 \mathrm{mM}^{-\mathrm{K}^{+}}$was sufficient to decrease the response. This difference suggests that at $3 \mathrm{~min}$ the decrease in cytoplasmic $\mathrm{Ca}^{2+}$ is more resistant to inhibition of $\mathrm{Ca}^{2+}$ influx. This probably reflects the fact that at earlier time periods the contribution of $\mathrm{Ca}^{2+}$ mobilized from intracellular stores to cytoplasmic $\mathrm{Ca}^{2+}$ is still significant. After $10 \mathrm{~min}$, stimulation by vasopressin will depend entirely on increased $\mathrm{Ca}^{2+}$ influx, so it is to be expected that the response will be more sensitive to inhibition of $\mathrm{Ca}^{2+}$ entry. Further increases in $\mathrm{K}^{+}$concentration led progressively to further decreases in the vasopressin stimulation until the response was abolished at about $80 \mathrm{~mm}^{-\mathrm{K}^{+}}$.

Increased $\mathrm{K}^{+}$begins to affect the stimulation of both $\mathrm{Ca}^{2+}$ influx and phosphorylase $a$ activity by vasopressin

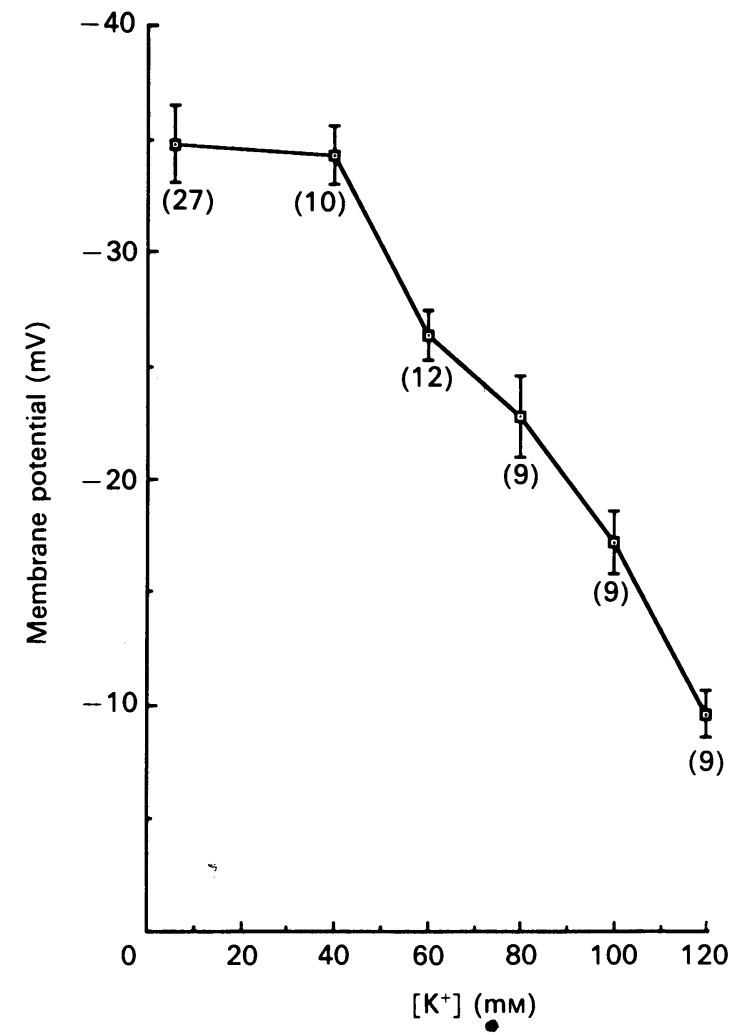

Fig. 5. Effect of varying the external $\left[\mathrm{K}^{+}\right]$on the plasmamembrane potential of hepatocytes

Hepatocytes, at a concentration of approx. $14 \mathrm{mg} / \mathrm{ml}$ dry cell wt., were incubated in medium containing varying $\left[\mathrm{K}^{+}\right]$with $0.7 \mu \mathrm{Ci}$ of ${ }^{36} \mathrm{Cl}^{-} / \mathrm{ml}$. The cells were incubated for 15 min to allow the ${ }^{36} \mathrm{Cl}^{-}$uptake to reach a steady state, and triplicate $500 \mu \mathrm{l}$ samples were removed. The samples were centrifuged through oil to separate the cells from the medium, and total pellet radioactivity (c.p.m.) was determined. The volume of contaminating extracellular fluid in the pellet was calculated from parallel incubations containing $2 \mu \mathrm{Ci}$ of $\left[{ }^{3} \mathrm{H}\right]$ inulin $/ \mathrm{ml}$. The total pellet volume was similarly determined from incubations containing $3 \mu \mathrm{Ci}$ of ${ }^{3} \mathrm{H}_{2} \mathrm{O} / \mathrm{ml}$. The intracellular volume of the cells in the pellet was taken as the difference between the ${ }^{3} \mathrm{H}_{2} \mathrm{O}$ and $\left[{ }^{3} \mathrm{H}\right]$ inulin spaces. Cellular uptake of ${ }^{36} \mathrm{Cl}^{-}$ was estimated from the total pellet radioactivity corrected for radiolabel in the extracellular fluid, and intracellular $\left[\mathrm{Cl}^{-}\right]$was calculated. The membrane potential was obtained from the equilibrium potential for $\left[\mathrm{Cl}^{-}\right]$given by the Nernst equation. The numbers in parentheses represent the numbers of incubations in a given $\left[\mathrm{K}^{+}\right]$from a total of 15 livers. Each incubation was sampled in triplicate. The data presented represent means \pm S.E.M.

at $30-50 \mathrm{~mm}-\mathrm{K}^{+}$. However, to abolish the vasopressin stimulation of $\mathrm{Ca}^{2+}$ influx required $114 \mathrm{mM}-\mathrm{K}^{+}$, whereas the activation of phosphorylase $a$ was blocked at lower concentrations of $\mathrm{K}^{+}$, depending on the time period observed (Figs. 2 and 4). It appears, then, that it is not necessary to block the stimulation of $\mathrm{Ca}^{2+}$ influx by vasopressin completely to abolish stimulation of phosphorylase.

The obvious effect of substituting $\mathrm{K}^{+}$for $\mathrm{Na}^{+}$in the external medium is to depolarize the plasma membrane. Fig. 5 shows the effect of $\mathrm{K}^{+}$substitution for $\mathrm{Na}^{+}$on the plasma-membrane potential. In normal medium, the resting potential was $-35 \mathrm{mV}$, in close agreement with 
previous reports (Hoek et al., 1980; Bradford et al., 1985). Increasing the $\mathrm{K}^{+}$concentration at the expense of $\mathrm{Na}^{+}$to $40 \mathrm{~mm}$ had little effect on the membrane potential, but further increases in the $\mathrm{K}^{+}$concentration led to a depolarization of the membrane, until at $120 \mathrm{~mm}-\mathrm{K}^{+}$the plasma-membrane potential was decreased to $-10 \mathrm{mV}$.

The effects of increasing $\mathrm{K}^{+}$on the plasma-membrane potential show a similar profile to the effects on vasopressin-stimulated phosphorylase activity and on vasopressin-stimulated $\mathrm{Ca}^{2+}$ influx (Figs. 2, 4 and 5). However, the increase in $\mathrm{K}^{+}$is at the expense of a decrease in $\mathrm{Na}^{+}$, so it is possible that the effects observed result from the decrease in $\mathrm{Na}^{+}$concentration. This was tested by replacing $\mathrm{Na}^{+}$with $N$-methyl-D-glucamine ${ }^{+}\left(\mathrm{NMDG}^{+}\right)$ as an alternative to $\mathrm{K}^{+}$. Replacement of $\mathrm{Na}^{+}(120 \mathrm{mM})$ with $\mathrm{NMDG}^{+}$decreased the plasma-membrane potential from $-35 \mathrm{mV}$ to $-23 \mathrm{mV}$. Vasopressin-stimulated phosphorylase activity was decreased by $40 \%$ (Table 1 ), which was similar to the decrease in the vasopressin response observed when the same degree of depolarization was achieved with increased $\mathrm{K}^{+}$concentration $(60 \mathrm{~mm})$. However, with $120 \mathrm{mM}-\mathrm{NMDG}^{+}$the $\mathrm{Na}^{+}$con-

Table 1. Effect of $\mathrm{Na}^{+}$replacement on membrane potential and phosphorylase $a$ activity

Cells were incubated in the appropriate medium at a concentration of approx. $10 \mathrm{mg} / \mathrm{ml}$ dry cell wt. in the absence or presence of vasopressin $(10 \mathrm{nM})$. Samples were taken in triplicate at the times indicated and assayed for phosphorylase $a$ activity (as described in the Experimental section). The membrane potentials of the hepatocytes were determined as described in the legend to Fig. 5. The data are presented as percentages of basal phosphorylase $a$ activity $(100 \%)$, and are means \pm S.E.M. for three determinations.

\begin{tabular}{|c|c|c|}
\hline $\begin{array}{l}{\left[\mathrm{K}^{+}\right] \text {or }\left[\mathrm{NMDG}^{+}\right]} \\
(\mathrm{mM})\end{array}$ & $\begin{array}{c}\text { Membrane } \\
\text { potential } \\
(\mathrm{mV})\end{array}$ & $\begin{array}{c}\text { Phosphorylase } \\
a \text { activity } \\
\text { (\% of basal) }\end{array}$ \\
\hline $\begin{array}{l}6 \mathrm{mM}^{-\mathrm{K}^{+}} \\
60 \mathrm{mM}-\mathrm{K}^{+} \\
120 \mathrm{mM}-\mathrm{K}^{+}\end{array}$ & $\begin{array}{r}34.8 \pm 1.7 \\
26.4 \pm 1.1 \\
9.6 \pm 1.0\end{array}$ & $\begin{array}{c}411 \pm 21 \\
218 \pm 10 \\
76 \pm 5\end{array}$ \\
\hline $120 \mathrm{~mm}^{-\mathrm{NMDG}^{+}}$ & $23.5 \pm 1.2$ & $239 \pm 5$ \\
\hline
\end{tabular}

centration was $25 \mathrm{mM}$, whereas with $60 \mathrm{~mm}-\mathrm{K}^{+}$substitution the $\mathrm{Na}^{+}$concentration was $85 \mathrm{~mm}$. It appears therefore that the inhibition of vasopressin stimulation of phosphorylase and of $\mathrm{Ca}^{2+}$ influx is related to the depolarization of the plasma membrane, rather than to the change in $\mathrm{Na}^{+}$concentration.

It seemed unlikely that the effects of increasing $\mathrm{K}^{+}$ were the result of a non-specific effect on cell viability, since there was no change in the capacity of the cells to exclude Trypan Blue and no decrease in ATP (results not shown). To test this possiblity further, we examined the effect of $\mathrm{K}^{+}$substitution on the ability of glucagon to stimulate phosphorylase. There was no significant difference in the extent of stimulation $(400 \%)$ when the cells were suspended in normal medium or in medium containing $120 \mathrm{~mm}-\mathrm{K}^{+}$. This indicates that the glycogenolytic cascade was still fully functional. We also examined the reversal of the effects of high- $\mathrm{K}^{+}$medium on resuspending the cells in normal medium. Both the membrane potential and stimulation of phosphorylase by vasopressin were restored to a value close to the control value (Table 2). It seems that the effects of high $\mathrm{K}^{+}$on vasopressin stimulation result from a specific effect on $\mathrm{Ca}^{2+}$ influx rather than any general effect on cell function.

\section{General discussion}

Cittadini \& van Rossum (1978) reported that the rat hepatocyte plasma membrane does not contain a $\mathrm{Na}^{+} / \mathrm{Ca}^{2+}$ exchange carrier. We found that substitution of $\mathrm{KCl}$ for $\mathrm{NaCl}$ in the external medium had no effect on either basal or vasopressin-stimulated $\mathrm{Ca}^{2+}$ efflux (Fig. 3). This supports their conclusion that the $\mathrm{Na}^{+} / \mathrm{Ca}^{2+}$ exchanger is not present. The $\mathrm{Na}^{+} / \mathrm{Ca}^{2+}$ exchange carrier has the capacity for $\mathrm{Ca}^{2+} / \mathrm{Ca}^{2+}$ exchange, which leads to problems in interpreting ${ }^{45} \mathrm{Ca}^{2+}$-flux measurements. Its absence from liver means that measurements of the initial rate of ${ }^{45} \mathrm{Ca}^{2+}$ influx reflect net uptake.

Substitution of $\mathrm{K}^{+}$for $\mathrm{Na}^{+}$had no effect on basal $\mathrm{Ca}^{2+}$ influx, but abolished the vasopressin-stimulated $\mathrm{Ca}^{2+}$ influx which is required to maintain the hormone response beyond the initial phase. The initial phase depends on mobilization of $\mathrm{Ca}^{2+}$ from an intracellular source (Fig. 2). This is consistent with the observation that, although the initial stimulation of phosphorylase by vasopressin was not affected by high $\mathrm{K}^{+}$, stimulation was transient (Fig. 1). The time course was very similar to

Table 2. Is the effect of high $\mathrm{K}^{+}$on the membrane potential and the phosphorylase $a$ activity reversible?

Cells were preincubated in medium containing either $6 \mathrm{mM}-\mathrm{K}^{+}$or $120 \mathrm{~mm}-\mathrm{K}^{+}$for $15 \mathrm{~min}$. The cells were then centrifuged and resuspended in the same medium, except for a sample of the cells preincubated in $120 \mathrm{~mm}-\mathrm{K}^{+}$which was resuspended in 6 mM$\mathrm{K}^{+}$medium ('reversed' cells). After a $15 \mathrm{~min}$ recovery period, the plasma-membrane potential was determined as described in the legend to Fig. 5 and the phosphorylase $a$ activity determined (see the Experimental section) in the absence or presence of vasopressin (10 nM). The activity data are presented as $\mu \mathrm{g}$ of $P_{\mathrm{i}}$ generated $/ \mathrm{min}$ per $\mathrm{mg}$ dry cell wt. and as stimulation (\% of basal). The results are means \pm S.E.M., representative of three determinations.

\begin{tabular}{lccc}
\hline & \multicolumn{3}{c}{ Cells } \\
\cline { 2 - 4 } & $6 \mathrm{mM}-\mathrm{K}^{+}$ & $120 \mathrm{mM}-\mathrm{K}^{+}$ & 'Reversed' \\
\hline & & & \\
Membrane potential $(\mathrm{mV})$ & $34.8 \pm 1.7$ & $9.6 \pm 0.9$ & $28.3 \pm 1.6$ \\
Basal phosphorylase $a$ activity $(\mu \mathrm{g} / \mathrm{min}$ per $\mathrm{mg})$ & $1.79 \pm 0.04$ & $2.21 \pm 0.05$ & $1.96 \pm 0.05$ \\
Stimulated phosphorylase $a$ activity $(\mu \mathrm{g} / \mathrm{min}$ per $\mathrm{mg})$ & $5.91 \pm 0.08$ & $2.26 \pm 0.04$ & $5.79 \pm 0.13$ \\
Stimulation $(\%)$ & 330 & 102 & 295
\end{tabular}


that observed in normal- $\mathrm{K}^{+}$medium in the presence of EGTA. Merritt \& Rink (1987) measured the effects of carbamoylcholine on cytoplasmic $\mathrm{Ca}^{2+}$ in rat parotid acinar cells, using the fluorescent $\mathrm{Ca}^{2+}$ indicator Fura 2. They found that replacement of the $\mathrm{Na}^{+}$in the extracellular medium with $\mathrm{K}^{+}$decreased the extent and duration of the increase in $\mathrm{Ca}^{2+}$ in response to the agonist so that it was comparable with the increase in the absence of extracellular $\mathrm{Ca}^{2+}$. Similar results were reported in rat liver by Altin et al. (1988). This further supports the conclusion that $\mathrm{K}^{+}$substitution for $\mathrm{Na}^{+}$ inhibits an agonist-stimulated influx of $\mathrm{Ca}^{2+}$.

The most obvious effect of $\mathrm{K}^{+}$substitution for $\mathrm{Na}^{+}$is to depolarize the plasma membrane, as shown in Fig. 5. The potential determined in normal media was very similar to that measured in many previous reports by a variety of methods (Dambach \& Friedmann, 1974; Hoek et al., 1980; Wondergem, 1981; Smock et al., 1982; Bradford et al., 1985). Increasing $\mathrm{K}^{+}$at the expense of $\mathrm{Na}^{+}$had relatively little effect until a concentration of $40 \mathrm{mM}^{-} \mathrm{K}^{+}$was reached. Further increases caused a marked depolarization. This correlates closely with the amount of $\mathrm{K}^{+}$substitution required to inhibit the increase in phosphorylase activity by vasopressin at extended time periods (Fig. 1). There have been many reports that increased extracellular $\mathrm{K}^{+}$inhibits phosphorylase and glycogen breakdown or activates glycogen synthesis (Hastings et al., 1952; Cahill et al., 1957; Dambach \& Friedmann, 1974; Hue et al., 1975; Althaus-Salzmann et al., 1980). Replacement of $\mathrm{Na}^{+}$with $\mathrm{NMDG}^{+}$also affects both phosphorylase activation and plasma-membrane potential. The extent of the effect on phosphorylase correlates closely with the change in membrane potential and not with the change in $\mathrm{Na}^{+}$concentration (Table 1). Thus it appears that depolarization of the plasma membrane blocks the extended response to vasopressin. This suggests that the $\mathrm{Ca}^{2+}$ channels responsible for hormonestimulated $\mathrm{Ca}^{2+}$ influx are voltage-sensitive, but in the reverse sense to those in excitable cells, being closed rather than opened as a result of depolarization of the plasma membrane.

There are a number of reports which suggest that agonists that lead to an increase in cytoplasmic $\mathrm{Ca}^{2+}$ also hyperpolarize the plasma membrane. Using micro-electrodes, Jenkinson \& Koller (1977) found that $\alpha$-adrenergic agonists hyperpolarized the plasma membrane of guineapig liver. We are not aware of any direct determinations of the effect of vasopressin on rat liver hepatocyte plasmamembrane potential. However, it has been reported that vasopressin activates the $\mathrm{Na}^{+} / \mathrm{K}^{+}$-ATPase in rat hepatocytes, which probably results in an increase in plasma membrane potential (Capiod et al., 1982; RadominskaPyrek et al., 1982; Lynch et al., 1986). Taken together with our observation that plasma-membrane depolarization blocks hormone-stimulated $\mathrm{Ca}^{2+}$ influx, this raises the possibility that an agonist-induced increase in membrane potential may trigger increased $\mathrm{Ca}^{2+}$ influx. However, as yet there have been no reports of the effects of raising the plasma-membrane potential under circumstances where either cyclic AMP production or inositol phosphate release were not affected. The possibility remains that effects of changes in membrane potential may be secondary to effects on either cyclic AMP metabolism or inositol phospholipid metabolism.

The effect of depolarization may be either a direct effect on the $\mathrm{Ca}^{2+}$ channel itself or an effect on a messenger pathway required to open the $\mathrm{Ca}^{2+}$ channel. It has been suggested that hormones activate $\mathrm{Ca}^{2+}$ influx as a result of inositol phosphate release. In particular, it has been proposed that inositol 1,3,4,5-tetrakisphosphate may mediate the $\mathrm{Ca}^{2+}$ influx in response to hormones (Irvine \& Moor, 1986). Berridge (1981) reported that replacement of $\mathrm{Na}^{+}$with $\mathrm{K}^{+}$led to an inhibition of phosphatidylinositol turnover in blowfly salivary gland, but no detailed analysis of the effect on the production of individual inositol phosphates was performed. It is possible that the effect of depolarization on hormonestimulated $\mathrm{Ca}^{2+}$ influx is secondary to an effect on inositol phosphate release.

A. L.S. is supported by a S.E.R.C. studentship. M. B. was in receipt of a studentship from the M.R.C.

\section{REFERENCES}

Althaus-Salzmann, M., Carafoli, E. \& Jacob, A. (1980) Eur. J. Biochem. 106, 241-248

Altin, J. G., Biden, T. J., Karjalainen, A. \& Bygrave, F. L. (1988) Biochem. Biophys. Res. Commun. 153, 1282-1289

Bergmeyer, H. U. (1985) Methods Enzymic Anal. 3rd Ed. 7, 357-360

Berridge, M. J. (1981) in Drug Receptors and Their Effectors (Birdsall, N. J. M., ed.), pp. 75-85, MacMillan, Bristol

Berridge, M. J. (1987) Annu. Rev Biochem. 56, 159-193

Berry, M. N. \& Friend, D. S. (1969) J. Cell Biol. 43, 506-520

Blackmore, P. F., Waynick, L. E., Blackman, G. E., Graham, C. W. \& Sherry, R. S. (1984) J. Biol. Chem. 259, 1232212325

Bradford, M. N., Hayes, M. R. \& McGivan, J. D. (1985) Biochim. Biophys. Acta 845, 10-16

Burgess, G. M., Claret, M. \& Jenkinson, D. H. (1979) Nature (London) 279, 544-546

Cahill, G. F., Ashmore, J., Zuttu, S. \& Hastings, A. B. (1957) J. Biol. Chem. 224, 237-250

Capiod, T., Berthon, B., Poggioli, J., Burgess, G. M. \& Claret, M. (1982) FEBS Lett. 141, 49-52

Cittadini, A. \& van Rossum, G. D. V. (1978) J. Physiol. (London) 281, 29-43

Cocks, T. M., Jenkinson, D. H. \& Koller, K. (1984) Br. J. Pharmacol. 83, 281-291

Dambach, G. \& Friedmann, N. (1974) Biochim. Biophys. Acta 332, 374-386

Di Virgilio, F., Lew, P. D., Andersson, T. \& Pozzan, T. (1987) J. Biol. Chem. 262, 4574 4579

Gelfand, E. W., Cheung, R. K. \& Grinstein, S. (1984) J. Cell. Physiol. 121, 533-539

Friedmann, N. \& Park, C. R. (1968) Proc. Natl. Acad. Sci. U.S.A. 61, 504-508

Hansen, C. A., Mah, S. \& Williamson, J. R. (1986) J. Biol. Chem. 261, 8100-8103

Hastings, A. B., Teng, C. T., Nesbett, F. B. \& Sinex, F. M. (1952) J. Biol. Chem. 194, 69-81

Hoek, J. B., Nicholls, D. G. \& Williamson, J. R. (1980) J. Biol. Chem. 255, 1458-1464

Hue, L., Bontemps, F. \& Hers, H. G. (1975) Biochem. J. 152, 105-114

Hughes, B. P., Milton, S. E., Barritt, G. J. \& Auld, A. M. (1986) Biochem. Pharmacol. 35, 3045-3052

Irvine, R. F. \& Moor, R. M. (1986) Biochem. J. 240, 917-920

Jenkinson, D. H. \& Koller, K. (1977) Br. J. Pharmacol. 59, 163-175 
Joseph, S. K. \& Williamson, J. R. (1983) J. Biol. Chem. 258, 10425-10432

Joseph, S. K., Coll, K. E., Thomas, A. P., Rubin, R. \& Williamson, J. R. (1985) J. Biol. Chem. 260, 12508-12515

Krebs, H. A. \& Henseleit, K. (1932) Hoppe-Seyler's Z. Physiol. Chem. 210, 33-66

Lynch, C. J., Wilson, P. B., Blackmore, P. F. \& Exton, J. H. (1986) J. Biol. Chem. 261, 14551-14556

Mauger, J. P., Poggioli, J., Guesdon, F. \& Claret, M. (1984) Biochem. J. 221, 121-127

Merritt, J. E. \& Rink, T. J. (1987) J. Biol. Chem. 262, 1736217369

Radominska-Pyrek, A., Kraus-Friedmann, N., Lester, R., Little, J. \& Denkins, Y. (1982) FEBS Lett. 141, 56-58
Reinhart, P. H., Taylor, W. M. \& Bygrave, F. L. (1984a) Biochem. J. 220, 35-42

Reinhart, P. H., Taylor, W. M. \& Bygrave, F. L. (1984b) Biochem. J. 220, 43-50

Smock, T. K., van Dyke, R. W., Bissell, D. M. \& Scharshmidt, B. F. (1982) Gastroenterology 82, 1246

Stalmans, W. \& Hers, H. G. (1975) Eur. J. Biochem. 54, 341-350

Tsien, R. Y., Pozzan, T. \& Rink, T. J. (1982) Nature (London) 295, 68-71

van de Werve, G., van de Berghe, G. \& Hers, H. G. (1974) Eur. J. Biochem. 41, 97-102

van de Werve, G., Hue, L. \& Hers, H. G. (1977) Biochem. J. $162,135-142$

Wondergem, R. (1981) Am. J. Physiol. 241, C209-C214

Received 30 September 1988/1 February 1989; accepted 20 February 1989 